\title{
Factors Affecting Low Birth Weight Incidence at Cipto Mangunkusumo Hospital, Jakarta
}

\author{
Rachma F. Boedjang, Rinawati Rohsiswatmo, Titi S Sularyo, \\ Sudigdo Sastroasmoro
}

(Department of Child Health, Medical School, University of Indonesia, Jakarta)

\begin{abstract}
A case-control study was conducted during the period of April-July 1997 to determine factors affecting the incidence of low birth weight infants born at Cipto Mangunkusumo Hospital, Jakarta. Of the 300 singleton infants (150 LBW and 150 non-LBW) studied, five risk factors were determined: (1) maternal education ( $p=0,027)$, (2) matemal weight gain during pregnancy ( $\mathrm{p}<0,0001)$, (3) interval between pregnancy intervals $(p=0,041),(4)$ history of previous LBW $(p=0,004)$, and (5) maternal health condition during pregnancy $(\mathrm{p}<0,0001)$. The mean anthropometric measurements of male non-LBW were significantly greater than female non-LBW infants. [Paediatr Indones 1998; 38:255-264]
\end{abstract}

\section{Introduction}

Low birth weight (LBW) infants, that is infant weighing 2500 grams or less at birth, is associated with increased perinatal and infant mortality and morbidity. ${ }^{1.4}$ The infant mortality rate is 17 times higher in the LBW group than that in the non-LBW group..$^{5}$ On the other hand, LBW infants are prone to have sequelae such as neurological disorders, delayed physical growth, mental retardation, and learning difficulties. ${ }^{2.8}$ The incidence of LBW is still high, ranging from around $7 \%$ (in developed countries) to $19 \%$ (in developing countries). In Indonesia, until the end of the fifth Five Year Development Plan Program, the incidence of LBW was $15 \%{ }^{9}$ It is hoped that at the end of the next 5 years, the incidence of LBW in Indonesia can be lowered down to $10 \%{ }^{10}$ From the nutritional point of view, LBW can be divided into two categories: (1) intrauterine fetal

Author's address: Dr. Rachma F Boedjang, Department of Child Health, Medical School, University of Indonesia, Jakarta, Jalan Salemba 6, Jakarta 10430, Indonesa. Tel. 62-21-3155742, Fax. 3907743. 
growth retardation (IUGR), and (2) non-IUGR infants (i.e., preterm infants). ${ }^{2}$ According to Villar, ${ }^{11}$ and others, ${ }^{3,12}$ the most common long-term complications of IUGR are abnormal weight and height gains. In developing countries, IUGR is the most common cause of LBW, whilst in Indonesia no such data have been reported. ${ }^{13}$

Causes of LBW are multifactorial. ${ }^{3.11 .12}$ From the maternal side, factors associated with LBW include age, height, weight gain, education, occupation, interval between pregnancy, unwanted pregnancy, history of abortion, history of LBW, socio-economic status, and the quantity and quality of antenatal care. From the infant's side, these factors are gender, race, and genetics. Some interesting aspects concerning these factors have been reported by some authors. Alisjahbana et al. found that the mean birth weight and chest circumference of male LBW were significantly greater than female LBW, ${ }^{14}$ while Crosse reported that in a singleton birth the ratio of LBW female to male was $6: 7.4 .^{3}$ The objective of this study is to find data of risk factors that play a role in the development of LBW, without differentiating whether the LBW belongs to the IUGR or non-IUGR category. The data can also be used to find the mean anthropometric measurements of male and female LBW and non-LBW infants.

\section{Methods}

This case-control study was conducted at the Division of Perinatology, Department of Child Health, University of Indonesia, Cipto Mangunkusumo Hospital, Jakarta. The criteria for inclusion were as follows: (1) all live-birth, singleton babies, born at Cipto Mangunkusumo Hospital during the period of April 1- July 31 1997; (2) no clinically detectable anomaly at birth. An infant was subject to be excluded from this study if the mother showed any of these exclusion criteria: (1) unconscious or in serious illness during labor, (2) refused to participate in this study, and (3) had no antenatal record. Successful study subjects were then divided into two groups: (1) LBW (Case) group, consisted of 150 singleton neonates born weighing less than 2500 grams who were consecutively recruited; (2) Non-LBW (Control) group, consisted of all singleton infants with the birth weight of 2500 grams or more. They were chosen randomly using random number table from all babies met the study criteria during the study period. One hundred and fifty non-LBW infants were selected and served as Control group.

All needed data were processed by using Epi-Info v. 5.01 program or SPSS for Windows v. 6 . The following analyses were then performed. First, characteristics of both groups (LBW and non-LBW), i.e., gender, anthropometric measurements, and nutritional status were described. If the number of study subjects was large enough, odds ratio (OR) and its 95\% confidence intervals and hypothesis testing were conducted in some of the characteristics. Secondly, risk factors for LBW were determined using bivariate and multivariate (logistic regression) analyses. In both analyses, infant's gender and maternal factors (age, education, employment, weight gain, parity, interval 
between pregnancy, wanted/unwanted pregnancy, history of previous abortion, history of previous LBW, health condition, antenatal care) as the independent vatiable, and the LBW as the dependent variable. OR, 95\% confidence intervas (CI) and hypothesis test were then calculated/ conducted. The multivariate/logistic regression analysis were performed with the help of the SPSS v. 6.0 program, using forward stepwise selection with Wald statistical method.

Since the number was too small, we excluded maternal height and history of stillbirth from the study (6 mothers with height of less than $145 \mathrm{~cm}$ compared to 294 mothers with height of $145 \mathrm{~cm}$ or more; 4 mothers with history of still-birth compared to 296 mothers without history of stillbirth). Socio-economy status was also excluded due to lack of sufficient data.

\section{Results}

\section{Characteristics of the infants}

During the period of April 1 - July 31 1997, from 1043 infants delivered at the Division of Perinatology, Department of Child Health, University of Indonesia, Cipto Mangunkusumo Hospital, Jakarta, $266(19.0 \%)$ weighed less than 2.500 grams. One hundred and sixteen LBW was then excluded from the LBW group because of stillbirths (38), twins (34) and insufficient maternal data (44).

Table 1 shows that female births were insignificantly greater in the LBW group (52.3\%) than the non-LBW group. (Table 1)

Table 1. Relation of gender to LBW and non-LBW

\begin{tabular}{lcccccc}
\hline Gender & LBW & $\%$ & Non-LBW & $\%$ & 7otal & $\%$ \\
\hline Male & 71 & 47.7 & 78 & 52.3 & 149 & 100.0 \\
Female & 79 & 52.3 & 72 & 47.7 & 151 & 100.0 \\
\hline
\end{tabular}

OR $=0.8395 \%$ confidence interval $0.51 ; 1.35 x^{2}=0.65 \mathrm{df}=1 \mathrm{p}=0.420$

Male infants of the non-LBW group revealed greater anthropometric measurements of birth-weight, birth-length, head circumference and chest circumference significantly. In the LBW group, female infants showed greater anthropometric measurements insignificantly (Tables 2 and 3). From the 150 LBW infants, 57 (38.0\%) were of IUGR-LBW type and 93 (52.0\%) of premature/non-IUGR LBW type. See Table 4. 
258 Factors affecting $L B W$ incidence

Table 2. Mean anthropometric measurements, non-LBW group, by gender

\begin{tabular}{lllc}
\hline \multicolumn{1}{c}{ Anthropometric meas. } & \multicolumn{1}{c}{ Male $(\mathrm{n}=78)$} & \multicolumn{1}{c}{ Female $(\mathrm{n}=72)$} & $p^{\star}$ \\
\hline Birth weight $(\mathrm{g})$ & $3239.9(\mathrm{SD} 498.38)$ & $3085.4(\mathrm{SD} 432.95)$ & 0.045 \\
Birth length $(\mathrm{cm})$ & $48.7(\mathrm{SD} \mathrm{1.85)}$ & 48.0 (SD 1.68) & 0.020 \\
Head circumerence $(\mathrm{cm})$ & $34.1(\mathrm{SD} \mathrm{1.11)}$ & 33.7 (SD 1.05) & 0.023 \\
Chest circumerence $(\mathrm{cm})$ & $32.4(\mathrm{SD} \mathrm{1.73)}$ & 31.6 (SD 2.91) & 0.032 \\
\hline
\end{tabular}

* student's t-test

Table 3. Mean anthropometric measurements, LBW group, by gender

\begin{tabular}{llll}
\hline Anthropometric meas. & \multicolumn{1}{c}{ Male $(\mathrm{n}=71)$} & \multicolumn{1}{c}{ Female $(\mathrm{n}=79)$} & $p^{*}$ \\
\hline Birth weight $(\mathrm{g})$ & $2065.6(\mathrm{SD} 390.45)$ & $2084.6(\mathrm{SD} 309.72)$ & 0.741 \\
Birth length $(\mathrm{cm})$ & $43.4(\mathrm{SD} \mathrm{4.19)}$ & $43.6(\mathrm{SD} 2.66)$ & 0.760 \\
Head circumerence $(\mathrm{cm})$ & $31.2(\mathrm{SD} \mathrm{1.72)}$ & $31.3(\mathrm{SD} 2.12)$ & 0.756 \\
$\begin{array}{l}\text { Chest circumerence } \\
(\mathrm{cm})\end{array}$ & 28.1 (SD 2.43) & 28.3 (SD 2.29) & 0.521 \\
\hline
\end{tabular}

*student's t-test

Table 4. Relation of nutritional status to LBW and non-LBW

\begin{tabular}{llllc}
\hline \multicolumn{1}{c}{ Group } & SGA $(\%)$ & AGA $(\%)$ & LGA $(\%)$ & Total $(\%)$ \\
\hline LBW & $57(38.0)$ & $93(62.0)$ & $0(0.0)$ & $150(100.0)$ \\
Non-LBW & $1(0.7)$ & $134(89.3)$ & $15(10.0)$ & $150(100.0)$ \\
\hline
\end{tabular}

$x^{2}=76.47 ; d f=2 ; p<0.0001$. SGA=small for gestational age; $A G A=$ appropriate for gestational age; LGA=large for gestational age.

\section{Risk Factors of LBW}

Table 5 shows the results of bivariate analyses revealed that risk factors to LBW were maternal age, maternal education, maternal weight gain during pregnancy, interval between pregnancy, wanted/unwanted pregnancy, history of previous abortion, history of previous LBW, maternal health condition during pregnancy, and quality of antenatal care. 
On logistic regression analysis, it shows that risk factors of LBW were maternal weight gain during pregnancy, maternal education, history of previous LBW, interval between pregnancy, maternal health, and quality of antenatal care. See Table 6.

\section{Discussion}

The $19.0 \%$ incidence rate of LBW found in this study was comparable to the $12-20 \%$ rate found by Ministry of Health, RI, at some teaching hospitals until the year $1994 .^{7}$ This finding was higher than the $2.1-17.7 \%$ field study reported by Alisjahbana et al. at 7 rural areas in West Java. ${ }^{15,16}$ According to Alisjahbana, the high incidence rate in hospital cases was due to the fact that most of the subjects were referral cases. ${ }^{15,16}$

The chance of delivering LBW in this study were insignificantly greater in female rather than male infants, with a ratio of $79: 71$ or 1,1:1. (Table 1). This finding differs from the report of Crosse, where the male to female ratio was of $7.4: 6 .^{3}$ So far, this difference can not be explained. A hormonal influence may play a role. ${ }^{17}$

The study of Alisjahbana et al. at 14 teaching hospitals in Indonesia comprising 5844 infants of various gestation ages concluded that anthropometric measurements of birth-weight, birth-length, head circumference, and chest circumference of male infants were greater that female infants, but only the birth-weight and chest circumference were significantly different. ${ }^{18}$ In this study similar measurement differences were found, but none were significant. (Data not supplied). Moreover, the non-LBW group showed a greater measuring size for male rather than female infants significantly (Table 2). On the other side, in the LBW group, female showed greater measurements than male infants insignificantly (Tabel 3). To define the cause of this phenomenon, further studies are imperatively needed.

LBW can be categorized into true premature/appropriate for gestational age (AGA), small for gestational age (SGA)/IUGR, and large for gestational age (LGA) infants. ${ }^{3,4}$ Table 4 shows that incidence of SGA/IUGR infants among LBW was $38.0 \%$. This result was higher than the $24.1 \%$ incidence rate found by Rohimi at the same hospital (1996). ${ }^{19}$ Meanwhile, Alisjahbana et al. found an incidence rate of $60 \%$ at Hasan Sadikin Hospital (Bandung). ${ }^{20}$ But officially, the national incidence rate of IUGR amongst LBW has not been reported. The great discrepancies of SGA/IUGR incidence rate amongst LBW at both hospitals may be caused by differences in the number of referral cases sent to each hospital. Moreover, the incidence of SGA/IUGR amongst LBW found in field survey was greater than at the hospitals. With similar birthweights, LBW-SGA has longer gestational age than true premature/AGA infants. This condition helps the LBW-SGA infants to adapt better to extrauterine environment, and to be less referred to the hospital. Alisjahbana et al. found that $70 \% \mathrm{LBW}$ infants born in Tandjungsari village were SGA. ${ }^{20}$

Through the logistic regression analysis, maternal risk factors found in this study 
were education, interval between pregnancy, weight gain during pregnancy, history of previous LBW, health condition during pregnancy, and adequate antenatal care. Other maternal factors (age, unwanted pregnancy, and history of previous abortion) did not appear in the multivariat analysis, but emerged in the bivariate analysis. Theimportance of the 3 maternal factors in bivariate analysis was caused by an additional factors that supportecl their roles as risk factors of LBW. This factor is called as a positive role factor. For example, an addition of age factor of the high risk mother to low education can lead to a definite risk factor of LBW. On the contrary, a high risk pregriant woman or woman bearing unwanted child or pregnant women with history of previous abortion can still have low risk of LBW if she has a good education, good health condition, or has interval between pregnancy, of less than 12 months, or has no bad history on her previous pregnancy, or she utilizes antenatal care adequately.

This study reveals that maternal occupation did not play an important role both in the bivariate and multivariate analyses. This phenomenon can be caused by the fact that the term matemal occupation did not specify body position at work, time/duration of work, weight of workload, etc. Table $\bar{\sigma}$ reveals that factor that had the lowest OR was history of previous LBW (OR $=0.25)$, while the highest OR was maternal health during pregnancy $(O R=5.27)$, followed by antenatal care quality $(O R=3.85)$ and interval between pregnancy (3.25). As far as OR is concerned, maternal education and antenatal care quality were risk factors that had the least OR.

Similar study conducted by Wibowo in Ciawi village (Bogor), ${ }_{2}^{21}$ and Alexander et al. at Hawaii, ${ }^{22}$ revealed that - besides the maternal education factor - a good paternal education level also played important role in lowering incidence of LBW, and viceversa. In a paternalistic country such as Indonesia, the role of father as the head of the family automatically give him the authority to be the decision maker. This condition should be evaluated in any objective of lowering incidence of LBW. Education is an agent of changing that can change the value and norms of a family. By education, one can receive more information and expand their way of thinking. This will help one to make decision more wisely. Mother and/or father with low education level will have difficulties to receive innovation. Most of them will also be unable to raise their family's welfare, hard to understand the importance of antenatal care, hard to receive the importance of family planning which will naturally be followed by a raise of the risk factors of LBW. Adding the paternal education factor to a similar study in the future, hopefully can reveal better contribution toward lowering risk factor of LBW.

This study bears some limitations. Firstly, several possible biases should be considered, i.e., recall bias and interviewer biases. Both forms of bias have been cautiously considered in the measurments. Recall bias was reduced by use of antenatal record data. Interviewer bias was possible since the study was not blinded; however, since the study did not involve any preferences, the bias was not considered serious.

Furthermore, the results of this study could not directly inferred into the general population, considering the very obvious difference between the characteristics of the 
Table 5. Bivariate analysis, risk factors of LBW

\begin{tabular}{|c|c|c|c|c|c|c|c|c|c|}
\hline \multicolumn{10}{|c|}{ Dependent Variable } \\
\hline \multicolumn{2}{|c|}{ Independent Variable } & \multicolumn{2}{|c|}{ LBW } & \multicolumn{2}{|c|}{ Non-LBW } & \multirow[t]{2}{*}{ OR } & \multirow[t]{2}{*}{$95 \%$} & \multirow[t]{2}{*}{$\mathrm{Cl}$} & \multirow[t]{2}{*}{$p$} \\
\hline & & $n$ & $\%$ & $n$ & $\%$ & & & & \\
\hline \multirow[t]{2}{*}{ Infant's gender } & male & 71 & 47.7 & 78 & 52.3 & 0.83 & 0.51 & 1.35 & 0.420 \\
\hline & female & 79 & 52.3 & 72 & 47.7 & & & & \\
\hline \multirow[t]{3}{*}{ Maternal age } & $<20$ years & 11 & 78.6 & 3 & 21.4 & 4.25 & 1.06 & 19.96 & 0.007 \\
\hline & $20-35$ yrs & 118 & 46.3 & 137 & 53.7 & 1.00 & & & \\
\hline & $>35$ years & 21 & 67.7 & 10 & 32.3 & 2.44 & 1.03 & 5.85 & \\
\hline \multirow[t]{2}{*}{ Maternal education } & $<6$ years & 47 & 59.5 & 32 & 41.5 & 1.68 & 0.96 & 2.95 & 0.066 \\
\hline & $>6$ years & 103 & 46.6 & 118 & 53.4 & & & & \\
\hline \multirow[t]{3}{*}{ Maternal occupation } & informal & 13 & 56.5 & 10 & 43.5 & 1.4 & 0.54 & 3.64 & 0.573 \\
\hline & civil serviprvt & 31 & 54.5 & 26 & 45.6 & 1.28 & 0.68 & 2.41 & \\
\hline & house wife & 106 & 48.2 & 114 & 51.8 & 1.00 & & & \\
\hline \multirow[t]{3}{*}{ weight gain } & $<9 \mathrm{~kg}$ & 109 & 95.6 & 5 & 4.4 & 57.91 & 20.14 & 179.7 & $<0.001$ \\
\hline & $9-11 \mathrm{~kg}$ & 32 & 27.4 & 85 & 72.6 & 1.00 & & & \\
\hline & $>11 \mathrm{~kg}$ & 9 & 13.0 & 60 & 87.0 & 0.74 & 0.28 & 1.96 & \\
\hline \multirow[t]{3}{*}{ Parity } & 1 & 109 & 52.0 & 101 & 48.0 & 1.00 & & & 0.558 \\
\hline & $2-3$ & 26 & 44.0 & 33 & 56.0 & 0.73 & 0.39 & 1.36 & \\
\hline & $>4$ & 15 & 48.4 & 16 & 51.6 & 0.87 & 0.38 & 1.98 & \\
\hline \multirow[t]{2}{*}{ Interval btw Pregn } & $<12$ mo & 85 & 56.0 & 67 & 44.0 & 1.62 & 1.00 & 2.64 & 0.041 \\
\hline & $>12 \mathrm{mo}$ & 65 & 44.0 & 83 & 56.0 & & & & \\
\hline \multirow[t]{2}{*}{ Wanted pregnancy } & No & 38 & 69.1 & 17 & 30.9 & 2.65 & 1.36 & 5.24 & 0.002 \\
\hline & Yes & 112 & 45.7 & 133 & 54.3 & & & & \\
\hline \multirow[t]{2}{*}{ History of abortion } & Yes & 30 & 71.4 & 12 & 28.6 & 2.88 & 1.33 & 6.29 & 0.003 \\
\hline & No & 120 & 46.5 & 138 & 53.5 & & & & \\
\hline \multirow[t]{2}{*}{ History of LBW } & Yes & 20 & 77.0 & 6 & 23.0 & 3.69 & 1.34 & 10.72 & 0.004 \\
\hline & No & 130 & 47.4 & 144 & 52.6 & & & & \\
\hline \multirow[t]{2}{*}{ Maternal health } & Not healthy & 83 & 67.0 & 41 & 33.0 & 3.29 & 1.97 & 5.52 & $<0.001$ \\
\hline & Healthy & 67 & 38.0 & 109 & 62.0 & & & & \\
\hline \multirow[t]{2}{*}{ Antenatal care } & Not adequate & 46 & 76.7 & 14 & 23.3 & 4.30 & 2.14 & 8.75 & $<0.001$ \\
\hline & Adequate & 104 & 43.3 & 136 & 56.7 & & & & \\
\hline
\end{tabular}


Table 6. Logistic regression analysis to determine role of independen variables on the incidence of LBW birth

\begin{tabular}{lcccccc}
\hline Independent Variable & $\mathrm{B}$ & $\mathrm{SE}$ & WALD & $\mathrm{df}$ & $\mathrm{SIG}$ & $\mathrm{EXP}(\mathrm{B})$ \\
\hline $\begin{array}{l}\text { Weight gain } \\
\text { during pregnancy }\end{array}$ & 0.3811 & 0.0481 & 62.8647 & 1 & 0.0000 & 0.6831 \\
$\begin{array}{l}\text { Maternal education } \\
\text { History of LBW }\end{array}$ & 0.3244 & 0.1499 & 4.6812 & 1 & 0.0305 & 1.3832 \\
$\begin{array}{l}\text { IIIness during } \\
\text { pregnancy }\end{array}$ & -1.3744 & 0.4900 & 7.8678 & 1 & 0.0050 & 0.2530 \\
$\begin{array}{l}\text { Antenatal care } \\
\text { quality }\end{array}$ & 1.6617 & 0.3352 & 24.5702 & 1 & 0.0000 & 5.2682 \\
$\begin{array}{l}\text { Interval between } \\
\text { pregnancy }\end{array}$ & 1.1782 & 0.3321 & 12.5844 & 1 & 0.0004 & 3.2486 \\
\begin{tabular}{l} 
Constant \\
\hline
\end{tabular} & -1.9630 & 0.6845 & 8.2247 & 1 & 0.0041 & \\
\hline
\end{tabular}

subjects in this study, which were mostly referred patients that usually comprised mothers with high risk pregnancy.

In conclusion, in this hospital-based case control study, we have found that maternal health, history of low birth weight, quality of antenatal care, interval between pregnancy, weight gain during pregnancy, and maternal education are important predictors for LBW birth. Although results of the study could not be inferred directly to the population in general, it is reasonable that those factors should be seriously considered in preventing LBW birth in population in general.

\section{References}

1. WHO Expert Committee on Maternal and Child Health. Low birth weight, a tabulation information. In: Maternal health and safe motherhood program. Geneve, 1992.

2. Kramer VS. Determinants of low birth weight, a methodological assessment and meta analysis. WHO Bulletin 1987; 65:663-737. 
3. Crosse VM. Reduction of mortality and morbidity rate due to low birth weight. In : The preterm baby and other babies with low birth weight. London: Livingstone, 1971; 244-77.

4. Battaglia FC, Lubchenco LO. A practical classification of newborn infants by weight and gestational age. J Pediatr 1967; 71:159-63

5. Sidik NA. Tatacara rujukan BBLR. Disampaikan pada Tinjauan Nasional Hasil Program Rintisan Penanggulangan Kurang Enerji Protein Dengan Pengukuran Lingkar Dada dan Lingkar Kepala, Jakarta, 9 Maret, 1997.

6. Puffer RR, Serano CV. Patterns of birthweights. PAHO-WHO scientific publication 504, 1987.

7. Depkes RI DirJen Pembinaan Kesehatan Masyarakat Direktorat Bina Gizi Masyarakat. Program perbaikan gizi ibu hamil dalam upaya penurunan angka bayi berat lahir rendah. Disampaikan pada Lokakarya pemantapan program pencegahan BBLR, Ciloto, 17-19 Oktober 1994.

8. Behrman RE. The high risk infant. In: Behrman RE, Kliegman RM, Nelson WE, Eds. Nelson textbook of pediatrics; edisi ke-14. Philadelphia:Saunders, 1992; 439-51.

9. Gunawan N. Program keschatan ibu dalam Repelita VI. Disampaikan pada Lokakarya pemantapan program pencegahan bayi berat lahir rendah, Ciloto, 17-19 Oktober 1994.

10. Rencana Pembangunan Lima Tahun Keenam Bidang Kesehatan 1994/95 - 1998/99. DepKes RI, 1994.

11. Villar J Belizan J, Smeriglio V. Postnatal experiences of intra uterine growth retardation. In: Senterre J, Ed. Intra uterine growth retardation pathophysiology and clinical management. Nestle Nutrition Workshop Series. New York: Raven Publication, 1989; 261-80.

12. Rosso P. Morbidity and mortality in intra uterine growth retardation. In: Senterre J, Ed. Intra uterine growth retardation, pathophysiology and clinical management. Nestle Nutrition Workshop Series. New York: Raven Publication, 1989; 123-42.

13. Sjahid I. Upaya menurunkan prevalensi BBLR dari ibu hamil yang mempunyai risiko gizi melalui pemberian makanan tambahan. Disampaikan pada: Lokakarya Pemantapan Program Pencegahan BBLR, Ciloto, 17-19 Oktober, 1994.

14. Alisjahbana A, Chaerulfatah A, Usman A. Anthropometry of newborn infants born in 14 teaching centers in Indonesia, a multicenter study coordinated by the Perinatology Working Group of the Indonesian Society of Pediatrician. Pediatr Indones 1994; 34:62-123.

15. Alisjahbana A, Hamzah ES, Peeters R, et al. Perinatal mortality in seven selected rural West Java, Indonesia. Part II : Results of a longitudinal survey on pregnant women. Pediatr Indones 1990; 50:179-90.

16. Alisjahbana A, Peeters R, Meheus A. Perinatal mortality and morbidity in rural West Java, Indonesia. Part 1: Vital statistics based on cross sectional survey. Pediatr Indones 1990; 30:1-11.

17. Goldenberg RL. Intra uterine growth retardation, a standard for diagnosis. Am J Obstet Gynecol 1989; 61:271-77.

18. Alisjahbana A, Chaerulfatah A, Usman A. Anthropometry of newborn infants born in 14 teaching centers in Indonesia, a multicenter study coordinated by the Perinatology Working Group of the Indonesian Society of Pediatrician. Pediatr Indones 1994; 34:62-123.

19. Rohimi S. Sebaran karakteristik bayi berat lahir rendah, pertumbuhan janin terhambat dan prematur. Tesis. Jakarta: Bagian Ilmu Kesehatan Anak FKUI, 1996.

20. Alisjahbana A, Mintardaningsih, Sutresnawati S. Kurva pertumbuhan balita di Tanjungsari. Disampaikan pada Pertemuan Direktorat Bina Gizi Masyarakat DepKes RI, Jakarta, 29-30 Mei, 1996. 
21. Wibowo A. Pemanfaatan pelayanan antenatal, faktor-faktor yang mempengaruhi dan hubungannya dengan bayi berat lahir rendah. Disertasi. Jakarta: Universitas Indonesia, 1992.

22. Alexander RG, Cornelly DA. Prenatal care utilization, its measurement and relationship to pregnancy outcome. Am J Prev Med 1961; 265:1-6. 